\title{
Mitigation of Milk Production Risk in Cattle Farming. Case Study on Animal Husbandry Mahesa Perkasa Farm, Depok City, West Java, Indonesia
}

\author{
Akhmad Riyadi Wastra ${ }^{a *}$, Rizki Adi Puspita Sari ${ }^{b}$, and Fernanda Aghnia Hafiza \\ ${ }^{\mathrm{a}, \mathrm{b}, \mathrm{c}}$ Department of Agribusiness \\ Syarif Hidayatullah State Islamic University Jakarta \\ Tangerang Selatan, Indonesia \\ *Email: riyadi.wastra@uinjkt.ac.id
}

\begin{abstract}
Mahesa Perkasa Farm is one of the largest cattle ranches in Sawangan District which is in direct need of risk management in producing cow's milk. The advent of risks to cow's milk production will have a negative impact on livestock and many farms are unable to recover quickly from these negative effects. Therefore, it is necessary to take risks or mitigation measures to reduce the impact of the risks. This research aims to (1) Identifying the risks that arise during the process of cow milk production at Mahesa Perkasa Farm. (2) Measuring the extent of cow milk production risk in Mahesa Perkasa Farm. (3) Mapping the risk of cow milk production at Mahesa Perkasa Farm. (4) Analyzing how to mitigate the risk of cow milk production at Mahesa Perkasa Farm. The analysis used by fishbone diagrams, the house of risk stage 1 (HOR 1), pareto diagram, and the house of risk stage 2 (HOR 2). The results of this research revealed that there were 8 risk events on the dairy cattle maintenance stage, 13 risk events on milking stage, 3 risk events on the packing stage and 50 causes of the overall risks. Based on the stage 1 HOR table, it was determined that the cause of risk with the highest score were 9 causes of risk on the dairy cattle breeding stage, 17 causes of risk on milking stage and 4 causes on the packing stage. Based on the priority of the cause of the risk, it determined that there were 20 mitigations that could be implemented to reduce the cause of the risks.
\end{abstract}

Keywords: Risk, Cattle, Pareto diagrams, House of Risk

\section{Introduction}

Fresh milk is one of the foods that are easily damaged. Milk damage can be caused by microbial contamination of milk and contamination of odors in the environment. In addition, fresh milk is easily damaged when handling is not good, so it has a relatively short shelf life. To deal with the milk damage that occurs, every business requires a good management effort from upstream to downstream. Mahesa Perkasa Farm, which was established in 2006, is a large scale dairy farm business owned by $\mathrm{Mr}$ Dendy Prihanggo, in producing fresh milk cow in Sawangan subdistrict, Depok, West Java, Indonesia. There are 191 dairy cattle consists of 105 lactating cows, 33 dry pregnant cows, 14 bulls, 16 cows ready to mate, and 23 calves. Any activity or business undertaken can not be separated from the risks of different types and characteristics. In conducting its business activities, Mahesa Perkasa Farm dairy farm experiences various risks, while the type of risk is considered to have the greatest influence in the production of milk occurs in the process of raising dairy cattle, milking process, and the process of packing fresh milk. According to the owner of the farm, this happens due to several factors such as worker errors, climate and changing weather, and inadequate environment that can cause the disease. Therefore, in this study, we identified the risks that arise during the process of milk production, measured the extent of milk production risk, mapped the risk of milk production and analyzed how to mitigate the risk of milk production at Mahesa Perkasa Farm.

\section{Research Method}

The method used in this study is House of Risk (HOR) stage 1 and 2 . HOR is used to manage risk by identifying risk and designing risk mitigation strategy so that it can reduce the occurrence of risk that exist [1].

\section{Results And Discussion}

3.1 Risk Events and Risk Causes

Risk measurement results are indicated in the table 1 and 2.

Table 1. List of Risk Events

\begin{tabular}{|c|c|c|c|c|}
\hline Process & Areas & Codes & Risk Events & SI \\
\hline \multirow[t]{8}{*}{$\begin{array}{l}\text { Dairy cattle } \\
\text { maintenance }\end{array}$} & $\begin{array}{l}\text { Feeding } \\
\text { and } \\
\text { drinking }\end{array}$ & E1 & Cattle are sick & 3.8 \\
\hline & & E2 & $\begin{array}{l}\text { Milk production } \\
\text { decreased }\end{array}$ & 3.4 \\
\hline & & E3 & $\begin{array}{l}\text { Data collection is } \\
\text { not appropriate }\end{array}$ & 2.3 \\
\hline & $\begin{array}{l}\begin{array}{l}\text { Checking } \\
\text { health }\end{array} \\
\end{array}$ & E4 & $\begin{array}{l}\text { There is a } \\
\text { contagious disease }\end{array}$ & 2.8 \\
\hline & & E5 & $\begin{array}{l}\text { Infection in cattle } \\
\text { limbs }\end{array}$ & 1.7 \\
\hline & $\begin{array}{l}\text { Cleaning } \\
\text { cage }\end{array}$ & E6 & $\begin{array}{l}\text { Microbial and } \\
\text { odor } \\
\text { contamination }\end{array}$ & 2.3 \\
\hline & & E7 & There are ticks & 3.5 \\
\hline & $\begin{array}{l}\text { Cleaning } \\
\text { cattle }\end{array}$ & E8 & $\begin{array}{l}\text { There is dirt in the } \\
\text { body of cattle }\end{array}$ & 3.6 \\
\hline
\end{tabular}


Table 1. List of Risk Events (Cont.)

\begin{tabular}{|c|c|c|c|c|}
\hline $\begin{array}{l}\text { Proc } \\
\text { ess }\end{array}$ & Areas & $\begin{array}{l}\text { Code } \\
\text { S }\end{array}$ & Risk Events & SI \\
\hline \multirow[t]{13}{*}{$\begin{array}{l}\text { Milk } \\
\text { ing }\end{array}$} & $\begin{array}{l}\text { Sanitation of } \\
\text { equipment and dairy } \\
\text { machinery }\end{array}$ & E9 & $\begin{array}{l}\text { Equipment and dairy } \\
\text { machines are not sterile }\end{array}$ & 2.5 \\
\hline & $\begin{array}{l}\text { Preparation } \\
\text { milker operation }\end{array}$ & E10 & $\begin{array}{l}\text { Contamination of germs } \\
\text { from workers }\end{array}$ & 2.9 \\
\hline & \multirow[t]{2}{*}{$\begin{array}{l}\text { Cleaning udders and } \\
\text { checking milk }\end{array}$} & E11 & $\begin{array}{l}\text { Bacterial contamination } \\
\text { on the udder }\end{array}$ & 3.1 \\
\hline & & E12 & Unleaded dirty milk & 3.0 \\
\hline & \multirow{2}{*}{$\begin{array}{lr}\begin{array}{l}\text { Machine } \\
\text { and installation } \\
\text { milking }\end{array} & \text { operating } \\
\end{array}$} & E13 & Cattle are stress & 4.7 \\
\hline & & E14 & Milk stuttered & 3.5 \\
\hline & \multirow{2}{*}{$\begin{array}{l}\text { Cleaning udders and } \\
\text { milk scraps } \\
\text { manually }\end{array}$} & E15 & $\begin{array}{l}\text { Blister and wound } \\
\text { udders }\end{array}$ & 4.1 \\
\hline & & E16 & The udder becomes long & 3.1 \\
\hline & Cleaning pest & E17 & $\begin{array}{l}\text { Cattle are infected with } \\
\text { mastitis }\end{array}$ & 4.9 \\
\hline & \multirow[t]{3}{*}{ Filtering milk } & E18 & $\begin{array}{l}\text { Milk spilled while } \\
\text { filtering }\end{array}$ & 4.1 \\
\hline & & E19 & Odor contamination & 3.1 \\
\hline & & E20 & $\begin{array}{l}\text { Bacteria and microbe } \\
\text { contamination }\end{array}$ & 3.0 \\
\hline & $\begin{array}{l}\text { Production } \\
\text { recording }\end{array}$ & E21 & Production data is lost & 3.2 \\
\hline \multirow{3}{*}{$\begin{array}{l}\text { Pack } \\
\text { ing } \\
\text { milk }\end{array}$} & $\begin{array}{l}\text { Storage in the } \\
\text { cooling unit }\end{array}$ & E22 & Milk is broken & 3.7 \\
\hline & \multirow[t]{2}{*}{ Packing } & E23 & The packaging is leaking & 3.2 \\
\hline & & E24 & $\begin{array}{l}\text { Milk spilled while } \\
\text { packing }\end{array}$ & 3.4 \\
\hline
\end{tabular}

Based on the results from table 1 above, it can be identified from 24 risk events that the value given is based on the severity or the effect of the risk occurrence, the greater the severity generated, the greater the value given. As well as the severity value, the amount of the value given is based on the degree of occurrence or frequency of the cause of the risk causing the disruption to the process flow. The greater the value assigned indicates the level of frequency that causes the risk to appear more frequently. The following table summarizes information about the value of occurrence in the cause of risk or the occurrence factor of 24 risk events above.

Table 2. List of risk causes

\begin{tabular}{|c|c|c|c|c|}
\hline Process & Areas & Code & Risk Agent & $\mathbf{O j}$ \\
\hline \multirow{10}{*}{$\begin{array}{l}\text { Dairy } \\
\text { cattle } \\
\text { maintena } \\
\text { nce }\end{array}$} & \multirow{6}{*}{$\begin{array}{l}\text { Feeding } \\
\text { and } \\
\text { drinking }\end{array}$} & A1 & Delay in feeding & 4,1 \\
\hline & & A2 & $\begin{array}{l}\text { The feed is contaminated } \\
\text { with bacteria }\end{array}$ & 4,4 \\
\hline & & A3 & $\begin{array}{l}\text { Drinking water } \\
\text { contaminated with dirt }\end{array}$ & 4,2 \\
\hline & & A4 & $\begin{array}{ll}\text { Changes in the } \\
\text { composition of } \\
\text { concentrate feed }\end{array}$ & 4,7 \\
\hline & & A5 & $\begin{array}{l}\text { Feed data has not been } \\
\text { updated }\end{array}$ & 3,4 \\
\hline & & A6 & $\begin{array}{l}\text { The data collection of feed } \\
\text { is not complete }\end{array}$ & 3,3 \\
\hline & \multirow[t]{4}{*}{$\begin{array}{l}\text { Checking } \\
\text { health }\end{array}$} & A7 & $\begin{array}{l}\text { Health check-up is not } \\
\text { done routinely }\end{array}$ & 4,1 \\
\hline & & A8 & $\begin{array}{l}\text { Provision of vitamins, } \\
\text { vaccines and worm drugs } \\
\text { is not done routinely }\end{array}$ & 3,8 \\
\hline & & A9 & $\begin{array}{l}\text { Workers do not cut cattle's } \\
\text { nails }\end{array}$ & 2,9 \\
\hline & & A10 & $\begin{array}{l}\text { Sick cattle are not } \\
\text { separated }\end{array}$ & 3,9 \\
\hline
\end{tabular}

Table 2. List of risk causes (Cont.)

\begin{tabular}{|c|c|c|c|c|}
\hline $\begin{array}{l}\text { Proces } \\
\text { S }\end{array}$ & Areas & $\begin{array}{l}\text { Cod } \\
\text { e }\end{array}$ & Risk Agent & $\mathbf{O j}$ \\
\hline \multirow{5}{*}{$\begin{array}{l}\text { Dairy } \\
\text { cattle } \\
\text { mainte } \\
\text { nance }\end{array}$} & \multirow[t]{5}{*}{$\begin{array}{l}\text { Cleaning } \\
\text { cage }\end{array}$} & A11 & $\begin{array}{l}\text { Lots of dirt and cattle urine in the } \\
\text { cage }\end{array}$ & 3,8 \\
\hline & & $\mathrm{A} 12$ & Workers neglect to clean the cage & 3,2 \\
\hline & & A13 & Supervision is less than optimal & 3,1 \\
\hline & & A14 & $\begin{array}{l}\text { Workers just spray water on the } \\
\text { body of cattle }\end{array}$ & 3,1 \\
\hline & & A15 & $\begin{array}{l}\text { Workers do not brush the cattle } \\
\text { body }\end{array}$ & 3,3 \\
\hline \multirow[t]{29}{*}{$\begin{array}{l}\text { Milkin } \\
\mathrm{g}\end{array}$} & \multirow{3}{*}{$\begin{array}{l}\text { Sanitation } \\
\text { of } \\
\text { equipment } \\
\text { and dairy } \\
\text { machinery }\end{array}$} & A16 & $\begin{array}{l}\text { Dairy equipment and machines } \\
\text { are not sterile }\end{array}$ & 2,3 \\
\hline & & A17 & $\begin{array}{l}\text { Workers do not use soap and } \\
\text { disinfectants }\end{array}$ & 4 \\
\hline & & A18 & $\begin{array}{l}\text { The equipment is only washed by } \\
\text { using water only }\end{array}$ & 4 \\
\hline & \multirow{2}{*}{$\begin{array}{l}\text { Machine } \\
\text { installation } \\
\text { and milking } \\
\text { operation }\end{array}$} & A19 & Workers are sick & 4 \\
\hline & & A20 & Working nails dirty workers & 3,7 \\
\hline & \multirow{6}{*}{$\begin{array}{l}\text { Cleaning } \\
\text { udders and } \\
\text { checking } \\
\text { milk }\end{array}$} & $\mathrm{A} 21$ & $\begin{array}{l}\text { The contamination of dirty } \\
\text { workers' hands }\end{array}$ & 3,5 \\
\hline & & $\mathrm{A} 22$ & The udder is not cleaned properly & 3,4 \\
\hline & & A23 & $\begin{array}{l}\text { The udder can not be paced warm } \\
\text { water }\end{array}$ & 2,3 \\
\hline & & A24 & $\begin{array}{l}\text { Workers do not check on the } \\
\text { cattle's udder before milking }\end{array}$ & 4,4 \\
\hline & & A25 & $\begin{array}{l}\text { Lack of worker knowledge about } \\
\text { mastitis disease }\end{array}$ & 4,3 \\
\hline & & A26 & $\begin{array}{l}\text { Workers chalked milk exposed to } \\
\text { mastitis }\end{array}$ & 4,3 \\
\hline & \multirow{7}{*}{$\begin{array}{l}\text { Machine } \\
\text { installation } \\
\text { and } \\
\text { operating } \\
\text { milking }\end{array}$} & A27 & $\begin{array}{lll}\begin{array}{l}\text { Employee } \\
\text { milking }\end{array} & \text { turnover } & \text { during } \\
\end{array}$ & 4,6 \\
\hline & & A28 & $\begin{array}{l}\text { The milking time interval is not } \\
\text { on schedule }\end{array}$ & 4,7 \\
\hline & & A29 & Noisy and dirty environment & 4 \\
\hline & & $\mathrm{A} 30$ & $\begin{array}{l}\text { Extreme weather changes (heat } \\
\text { and rain) }\end{array}$ & 4,6 \\
\hline & & $\mathrm{A} 31$ & $\begin{array}{l}\text { Remains of dirt in the hose of the } \\
\text { dairy machine }\end{array}$ & 2,3 \\
\hline & & $\mathrm{A} 32$ & Dairy apparatus less fit paired & 2,3 \\
\hline & & $\mathrm{A} 33$ & $\begin{array}{l}\text { Cattle experience lust (want to } \\
\text { mate) when milked }\end{array}$ & 3,5 \\
\hline & \multirow{4}{*}{$\begin{array}{l}\text { Cleaning } \\
\text { udders and } \\
\text { milk scraps } \\
\text { manually }\end{array}$} & $\mathrm{A} 34$ & Long worker's nails & 3 \\
\hline & & A35 & Workers do not apply vaseline & 4 \\
\hline & & A36 & $\begin{array}{l}\text { Workers are too hard to milk the } \\
\text { udder of the cattle }\end{array}$ & 4,2 \\
\hline & & A37 & The milking technique is wrong & 3,7 \\
\hline & \multirow{2}{*}{$\begin{array}{l}\text { Cleaning } \\
\text { pest }\end{array}$} & $\mathrm{A} 38$ & Late iodine fluid administration & 4,9 \\
\hline & & A39 & $\begin{array}{l}\text { Workers do not provide iodine } \\
\text { fluids }\end{array}$ & 5 \\
\hline & \multirow[t]{3}{*}{$\begin{array}{l}\text { Filtering } \\
\text { milk }\end{array}$} & A40 & $\begin{array}{l}\text { Workers are less careful when } \\
\text { filtering milk }\end{array}$ & 4 \\
\hline & & A41 & $\begin{array}{l}\text { The environment is not } \\
\text { supportive }\end{array}$ & 2,5 \\
\hline & & A42 & $\begin{array}{l}\text { Bacteria and microbes mixed into } \\
\text { milk }\end{array}$ & 3,2 \\
\hline & \multirow{2}{*}{$\begin{array}{l}\text { Production } \\
\text { recording }\end{array}$} & $\mathrm{A} 43$ & Recording is not done every day & 3,7 \\
\hline & & A44 & No data collection management & 3,5 \\
\hline \multirow{6}{*}{$\begin{array}{l}\text { Packin } \\
\text { g milk }\end{array}$} & \multirow{3}{*}{$\begin{array}{l}\text { Storage } \\
\text { into the } \\
\text { cooling unit } \\
\text { Milk } \\
\text { packing }\end{array}$} & A45 & Late storing into the cooling unit & 4,3 \\
\hline & & A46 & $\begin{array}{l}\text { Contamination of pathogenic } \\
\text { bacteria increases }\end{array}$ & 3,3 \\
\hline & & A47 & $\begin{array}{l}\text { Worker error when transporting } \\
\text { milk from cage to milk chamber }\end{array}$ & 3,8 \\
\hline & \multirow{3}{*}{$\begin{array}{l}\text { Storage } \\
\text { into the } \\
\text { cooling unit }\end{array}$} & A48 & $\begin{array}{l}\text { Packaging not in accordance with } \\
\text { SNI }\end{array}$ & 2,8 \\
\hline & & A49 & $\begin{array}{l}\text { Workers are less careful when } \\
\text { packing milk }\end{array}$ & 3,8 \\
\hline & & A50 & $\begin{array}{l}\text { Supervision is less than optimal } \\
\text { when milk packaging takes place }\end{array}$ & 3,2 \\
\hline
\end{tabular}


Based on the results of table 2 above, it can be estimated from 50 causes of the risk that the value of the occurrence is based on the frequency of the risk causing the disruption to the process flow. The greater the value assigned indicates the frequency of risk agents appeared more frequently.

\subsection{Risk Mapping}

According to [2], Risk mapping is done by using a pareto diagram. Pareto diagrams are graphs that sort the data down from left to right. Pareto diagram is a method of organizing errors, problems, or defects to help focus on problem-solving efforts. The diagram is used to clarify the problem, according to its causes and symptoms. The problem is presented in the form of diagrams by priority or importance by using bar charts. For example, based on the results of measurement severity, occurrence, and correlation, known calculation results of Aggregate Risk Potential (ARP) are sorted based on the highest to lowest value. The input from this table is as the result of the previously performed risk assessment. For example, after the input on the HOR stage 1, it is identified that 4 causes of risk with the highest ARP value in the process are packing cattle milk. The four causes of this risk are taken based on the cumulative ARP percentage in the $80 \%$ Pareto diagram of risk events caused by 4 causes of risk, as indicated in the figure 1 .

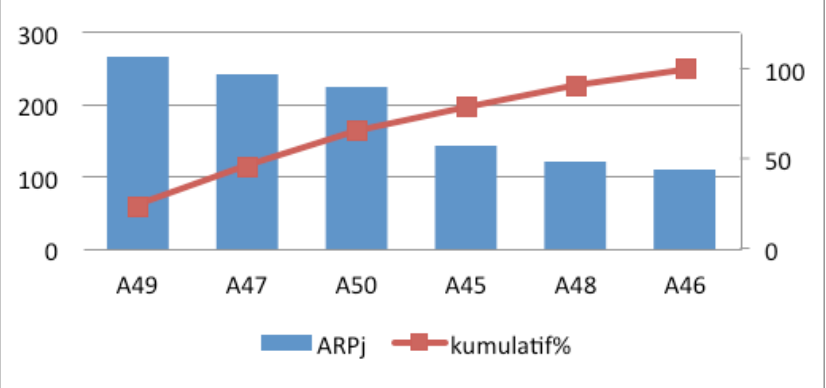

Figure 1. Risk mapping of milk packaging

Figure 1 indicates there are four causes of risk that are priority for handling: A49 (workers are less careful when packing milk) with value 267,90; A47 (Worker error when transporting milk) with value 242,82; A50 (less than optimal supervision during milk packaging) with a value of 225.60; A45 (late storing milk into cooling unit) with a value of 143,19 .

\subsection{Risk Mitigation}

Risk mitigation strategies are used to provide solutions to the risks posed. From risk mitigation, we obtained 20 mitigation strategies. The next step in creating a risk mitigation strategy is to use House of risk stage 2, which is used to determine the priority sequence of risk mitigation strategies. The selection of priority mitigation is based on the effectiveness of existing values, besides the mitigation strategy also based on the difficulty level of its application.
Table 3. Mitigation strategies

\begin{tabular}{|l|l|l|}
\hline Code & Mitigation action & $\mathrm{Dk}$ \\
\hline M1 & Performing performance evaluation & 3,6 \\
\hline M2 & Checking the health of dairy cattle regularly & 4 \\
\hline M3 & $\begin{array}{l}\text { Applying Animal Welfare (cage welfare) and } \\
\text { controlling the cage regularly }\end{array}$ & 3,6 \\
\hline M4 & Cooperating with many concentrate feed suppliers & 4,6 \\
\hline M5 & Creating a feed warehouse & 5 \\
\hline M6 & $\begin{array}{l}\text { Creating operational standard management of dairy } \\
\text { cattle cleanliness }\end{array}$ & 5 \\
\hline M7 & $\begin{array}{l}\text { Establishing operational standards and sustainable } \\
\text { maintenance management of cage cleanliness }\end{array}$ & 5 \\
\hline M8 & $\begin{array}{l}\text { Conducting vaccinations and health checks on } \\
\text { dairy cattle regularly }\end{array}$ & 3,6 \\
\hline M9 & Providing education to workers & 4 \\
\hline M10 & Improving coordination among workers & 3,6 \\
\hline M11 & Timetable and milking are clearly written & 3 \\
\hline M12 & Increasing stock availability of iodine solution & 4,6 \\
\hline M13 & Health checks for workers & 5 \\
\hline M14 & Keeping workers clean before applying milking & 3,6 \\
\hline M15 & $\begin{array}{l}\text { Creating operational standard and proper milking } \\
\text { procedures }\end{array}$ & 5 \\
\hline M16 & $\begin{array}{l}\text { Establishing communication with the Government } \\
\text { or the local Animal Husbandry Department to } \\
\text { conduct counseling and training to help farmers } \\
\text { problem }\end{array}$ & 5 \\
\hline M17 & Implementation of biosecurity & 3,6 \\
\hline M18 & $\begin{array}{l}\text { Checking the condition of dairy cow before } \\
\text { milking }\end{array}$ & 3,6 \\
\hline M19 & Increasing vaseline stock availability & 4 \\
\hline M20 & Perform performance evaluation & 4 \\
\hline M21 & $\begin{array}{l}\text { Creating standard operational prosedures and } \\
\text { correct milk handling procedures } \\
\text { : Mitigation difficulty level }\end{array}$ \\
\hline Dk & 5 \\
\hline
\end{tabular}

\begin{tabular}{|c|c|c|c|}
\hline $\begin{array}{l}\quad \begin{array}{l}\text { Risk } \\
\text { mitigation }\end{array} \\
\text { Risk agent }\end{array}$ & $\begin{array}{l}\text { 1. Carrying out a } \\
\text { performance } \\
\text { evaluation }\end{array}$ & $\begin{array}{l}\text { 2. Creating a } \\
\text { standard } \\
\text { operating } \\
\text { procedure for } \\
\text { milk handling } \\
\text { and packing }\end{array}$ & $\mathrm{ARP}_{\mathrm{j}}$ \\
\hline $\begin{array}{lr}\begin{array}{l}\text { Workers } \\
\text { careless } \\
\text { packing milk }\end{array} & \text { when } \\
\end{array}$ & 9 & 9 & 267.9 \\
\hline $\begin{array}{l}\text { Worker error while } \\
\text { transporting milk } \\
\text { from cage to dairy } \\
\text { room }\end{array}$ & 9 & 9 & 242.82 \\
\hline $\begin{array}{l}\text { Less than optimal } \\
\text { supervision when } \\
\text { packing milk }\end{array}$ & 9 & 9 & 225.6 \\
\hline $\begin{array}{l}\text { Late storing of } \\
\text { milk into the } \\
\text { cooling unit }\end{array}$ & 9 & 9 & 143.19 \\
\hline Tek & 6457.05 & 6457.05 & \\
\hline Dk & 4 & 5 & \\
\hline ETDk & 1614.263 & 1291.41 & \\
\hline Rank & 1 & 2 & \\
\hline
\end{tabular}

Figure 2. HOR stage 2 on milk packaging

Based on the figure 2 above, it is found that the value given is based on the difficulty level of the mitigation strategy. The greater the value given indicates that the difficulty level is difficult to run and the smaller the value given indicates that the difficulty level is easy to run. 
Based on DK measurement results, the correlation between risk and risk mitigation and Tek and ETD, the result can be used as an input for the HOR stage 2 table. The order of proposed mitigation strategies in milk packing is (1) conducting performance evaluation; (2) establishing operational standards for milk handling and packaging. The mitigation strategy with a high degree of difficulty is creating standard operational procedures for milk handling and the smallest is conducting performance evaluation.

From the roof of the HOR stage 2, there are some strong positive correlations. When two mitigation actions have strong positive correlations, then the company can choose one of the mitigation actions of both. If there are some positive correlations, the two mitigation actions are positively related, then the company can combine between two interconnected mitigation actions. If there are some unrelated mitigation actions, then both mitigation actions must be run both. Furthermore, for the maintenance process of dairy cattle, there are eight priorities of risk management strategies, namely: (1) Conducting performance evaluation; (2) Implementing animal welfare (cage welfare) and regular cage control; (3) Regularly checking the health of dairy cattle; (4) Establishing good and sustainable operational standards and cage hygiene management procedures; (5) Providing vitamins, vaccines and worm medicines on dairy cattle regularly; (6) Establishing operational standards of good and proper dairy hygiene maintenance management procedures; (7) Partnering with many concentrate feed suppliers; (8) Creating a feed warehouse. While in the milking process, there are eleven priorities of risk management strategies, namely: (1) Providing education to workers; (2) Establishing good operational standards and proper milking procedures; (3) Applying animal welfare; (4) Improving coordination among workers; (5) Maintaining workers' hygiene before milking; (6) Worker health checking; (7) Implementing biosecurity; (8) Establishing communication with the local Animal Husbandry Department to conduct counseling and training to assist farmer's problems; (9) Increasing stock of iodine solution; (10) Scheduling milking clearly; (11) Increasing availability of vaseline stock.

\section{Conclusion}

The results of this study indicate that there were 24 risk events, including 8 risk events in the process of raising dairy cattle, 13 risk events in the cattle milking process and 3 risk events in the milk packaging process. Overall, there are 50 causes of risk, among which 15 causes of risks in the process of raising dairy cattle, 29 causes of risk in the process of milking and 6 causes of risk in the process of milk packing. Based on the predetermined priority risk, there are 20 mitigation strategies that can be applied to reduce the cause of those risks based on the level of effectiveness and difficulty to perform.

\section{References}

[1] Pujawan, I Nyoman dan Laudine H. Geraldine. (2009). House Of Risk: A Model for Proactive Supply Chain Risk Management. Bussiness Process Management Journal. Surabaya: ITS e-journal.

[2] Kuswandi dan Erna Mutiara. (2004). DELTA: Delapan Langkah dan Tujuh Alat Statistik untuk Peningkatan Mutu Berbasis Komputer. Jakarta: PT Elex Media Komputindo. 